\title{
SEBARAN SPASIAL ECENG GONDOK (ECHORNIA CRASSIPES) DI DANAU TONDANO
}

\author{
Agnes Tenly Moningkey ${ }^{1}$, Anatje Lihiang ${ }^{2}$, Mercy M. F. Rampengan ${ }^{3}$ \\ ${ }^{1}$ Mahasiswa Program Studi Biologi, Pascasarjana, Universitas Negeri Manado \\ ${ }^{2,3}$ Dosen Program Studi Biologi, Pascasarjana, Universitas Negeri Manado \\ e-mail: atmoningkey@gmail.com
}

\begin{abstract}
The growth of water hyacinth in the waters of Lake Tondano can affect the lake's ecosystem due to its rapid growth and spread. Water hyacinth is a weed that damages the aquatic environment which, if its growth and development are not controlled, will reduce the amount of light entering the waters, evapotranspiration, and reduce the amount of water and can accelerate the process of silting the waters of Lake Tondano. The research objective was to determine the distribution pattern of water hyacinth in Lake Tondano from 2015 to 2020. The research method was descriptive qualitative and spatially analyzed data using geographic information systems. The data used are primary and secondary data, obtained through observation and field surveys and documentation. Based on the results of spatial analysis, it is known that the distribution pattern of water hyacinth in Lake Tondano has increased from 2015 with an area of $465.59 \mathrm{Ha}$, in 2016 the area was $848 \mathrm{Ha}$, in 2017 the area was 999,695 and there was a change in area decline, in 2018 the area was $675.87 \mathrm{Ha}$, and 2019 the area was $366.36 \mathrm{Ha}$. and in 2020 the area of water hyacinth will increase to 995,797 hectares. The factors causing the uncontrolled distribution of water hyacinth in the waters of Lake Tondano can be due to the season (climate), sedimentation, or land use. The growth and development of water hyacinths have disrupted various community activities and have an impact on the process of silting the waters of the lake and damaging the beauty of Lake Tondano.
\end{abstract}

Keywords: Distribution, Water Hyacinth, Geographical Information System, Lake Tondano

\begin{abstract}
Abstrak: Tumbuhnya eceng gondok di perairan danau Tondano dapat mempengaruhi ekosistem perairan danau akibat proses pertumbuhan dan penyebarannya sangat cepat. Eceng gondok adalah gulma yang merusak lingkungan perairan yang bila tidak dikendalikan pertumbuhan dan perkembangannya, akan menurunkan jumlah cahaya yang masuk ke perairan, evapotranspirasi dan mengurangi jumlah air serta dapat mempercepat terjadinya proses pendangkalan perairan danau tondano. Tujuan penelitian adalah untuk mengetahui pola sebaran eceng gondok pada danau Tondano tahun 2015 sampai dengan tahun 2020. Metode penelitian bersifat deskriptif kualitatif dan analisis data secara spasial menggunakan sistem informasi geografis. Data yang digunakan adalah data primer dan sekunder, yang diperoleh melalui observasi dan survei lapangan maupun dokumentasi. Berdasarkan hasil analisis spasial, diketahui pola sebaran eceng gondok di danau tondano mengalami peningkatan dari tahun 2015 luas $465.59 \mathrm{Ha}$, tahun 2016 luas $848 \mathrm{Ha}$, tahun 2017 luas 999.695 dan terjadi perubahan penurunan luas, di tahun 2018 luas $675.87 \mathrm{Ha}$, dan 2019 luas 366.36 Ha, dan pada tahun 2020 luas eceng gondok bertambah menjadi $995.797 \mathrm{Ha}$. Faktor penyebab sebaran eceng gondok pada perairan danau tondano yang tidak terkendali dapat disebabkan karena musim (iklim), sedimentasi, ataupun penggunaan lahan. Pertumbuhan dan perkembangan eceng gondok tersebut, mengakibatkan berbagai aktivitas masyarakat terganggu dan berdampak pada proses pendangkalan perairan danau serta merusak keindahan danau tondano.
\end{abstract}

Kata Kunci: Sebaran, Eceng Gondok, Sistem Informasi Geografis, Danau Tondano

\section{PENDAHULUAN}

Keberadaan eceng gondok di perairan danau tondano, dikhawatirkan berdampak terhadap ekosistem atau lingkungan fisik. Krismono, dkk (2018:64) menjelaskan bahwa eceng gondok merupakan gulma air apabila tidak dikendalikan pertumbuhan dan perkembangannya akan mengurangi jumlah air di danau sehingga meningkatkan laju pendangkalan. Eceng gondok pula merusak 
lingkungan perairan antara lain meningkatkan evapotranspirasi, menurunkan jumlah cahaya yang masuk ke perairan dan mempercepat terjadinya proses pendangkalan (Kusrinah, dkk, 2016:28)

Danau tondano berperan penting dan memberikan kontribusi yang sangat besar di bidang pertanian, perikanan, ekonomi dan industri pada masyarakat sekitarnya. Menurut Wantasen, dkk (2015:1), danau Tondano telah ditetapkan masuk dalam 15 danau prioritas di Indonesia pada kesepakatan Bali tahun 2009 tentang Pengelolaan Danau yang Berkelanjutan. Selanjutnya, Sittadewi (2011:59) menyatakan sungai dan danau tondano berfungsi strategis dalam menunjang kehidupan masyarakat di sekitarnya terlebih khusus masyarakat yang berada di wilayah kabupaten Minahasa, dan Sulawesi Utara pada umumnya, karena dimanfaatkan sebagai sumber listrik, sumber irigasi, air bersih, air baku, lokasi budidaya perikanan darat dan kegiatan pariwisata.

Eceng gondok merupakan family Pontederiaceae yang hidup di daerah tropis maupun sub tropis Gerbono dan Siregar (2005:23). Tumbuhan ini sebagai gulma perairan yang bisa beradaptasi secara cepat, pada suhu berkisar $28-30^{\circ} \mathrm{C}$ dan kondisi $\mathrm{pH}$ berkisar 4-12 dan berada di perairan yang keruh serta dangkal eceng gondok dapat tumbuh secara ideal. Sebaliknya di perairan yang dalam dan jernih tumbuhan ini sulit tumbuh.

Eceng gondok adalah tumbuhan gulma yang hidup terapung di perairan yang dalam dan mengembangkan perakaran di dalam lumpur pada perairan dangkal (Juliani, dkk, 2017:2020). Eceng gondok berkembang biak dengan cara vegetatif maupun generatif. Secara vegetatif dapat melipat ganda dua kali dalam kurun waktu 7-10 hari, dalam kurun waktu 52 hari satu batang eceng gondok bisa berkembang seluas $1 \mathrm{~m}^{2}$. Sedangkan secara generatif eceng gondok mampu berkembang biak dengan biji (Deswandri dan Fadhillah,2018:16).

Pada umumnya, tanaman eceng gondok berkembang biak dan hidup di sekitar rawa, danau, sungai, kolam dangkal, dan tempat genangan air lainnya. Eceng gondok dapat beradaptasi dengan cepat di habitatnya seperti perubahan ketinggian air, dan arus, $\mathrm{pH}$, temperatur, racun dalam air, dan ketersediaan nutrien, dengan nutrient yang kaya nitrogen, potassium, dan fosfat pertumbuhan eceng gondok sangat cepat (Deswandri dan Fadhillah, 2018:14).

Pemanfaaatan teknologi penginderaan jauh dan sistem informasi geografi untuk penilaian dan pemantauan parameter ekosistem perairan danau di Indonesia sudah banyak dilakukan oleh beberapa peneliti (Trisakti, dkk, 2014:394). Menurut Johnston (1998) dalam Radiarta dan Sagala (2012), Sistem Informasi Geografis telah banyak dimanfaatkan di berbagai bidang kajian salah satunya adalah kajian kondisi lingkungan perairan. Lebih lanjut, Trisakti dkk (2014:394), melakukan kajian pengembangan metode penentuan luas permukaan air danau dan identifikasi tumbuhan air yang menutupi permukaan air danau Limboto.

Oleh sebab itu, penelitian ini bertujuan untuk mengetahui pola sebaran eceng gondok pada danau tondano tahun 2015 sampai dengan tahun 2020. Apabila pola sebaran tersebut dikaji dan ditampilkan dalam data spasial, dapat diperoleh hasil secara efisien dan menyeluruh untuk ditindaklanjuti sehingga dapat diupayakan dan diambil tindakan, baik untuk pengelolaan ataupun penyelesaian permasalahan ekosistem dan fungsi perairan di danau tondano.

\section{METODE}

Metode penelitian adalah penelitian terapan (applied research) bersifat deskriptif kualitatif. Tujuan dari penelitian deskriptif kualitatif ini adalah untuk membuat deskriptif, gambaran atau lukisan secara sistematis, faktual dan akurat (Moh. Nasir, 2009:54).

Data yang digunakan adalah data primer dan sekunder, diperoleh melalui observasi dan survei lapangan, serta mengumpulkan data-data yang diperlukan untuk mengetahui sebaran eceng gondok.

Analisis data menggunakan pendekatan spasial, yang terlebih dahulu dilakukan standarisasi data. Data yang digunakan meliputi data citra Landsat 8 OLI dan basemap daerah kajian. Data citra Landsat 8 OLI didapatkan dari hasil unduh pada situs web resmi USGS (U.S. Geological Survey) yaitu glovis.usgs.gov. Citra yang diunduh direkam pada tahun 2015-2020. Data basemap merupakan data vektor berupa shapefile Sulawesi utara yang diperoleh dari Badan Informasi Geospasial. 
Kemudian dilakukan koreksi radiometrik sebagai tahapan awal pra-pengolahan data untuk mendapatkan nilai piksel yang bebas dari gangguan atmosfer. Penelitian ini menggunakan saluran tampak dan saluran inframerah serta daerah kajian merupakan daerah perairan yang ditutupi vegetasi yang lebat sehingga koreksi radiometrik yang digunakan ialah TOA Reflectance dan sudut matahari (Sun Elevation) pada saluran 1 sampai 7. Adapun algoritma TOA Reflectance adalah sebagai berikut (USGS, 2013):

$$
\rho \lambda=M \rho Q c a l+A \rho / \text { Sin SE (Sun Elevation) }
$$

$$
\begin{aligned}
& \text { Keterangan: } \\
& \rho \lambda= \text { Hasil pengolahan TOA dengan menggunakan } \\
& \text { sudut pengambilan matahari. } \\
& \mathrm{Qcal}= \text { Nilai piksel (DN), diisikan band yang } \\
& \text { digunakan } \\
& \mathrm{MP}= \text { Konstanta rescalling } \\
& \text { (Reflectance_Mult_Band_x, di mana } \mathrm{x} \text { adalah } \\
& \text { band yang digunakan) }
\end{aligned}
$$

Setelah dilakukan koreksi radiometrik dilanjutkan dengan mengolah data citra menjadi data spasial (interpretasi) yang disajikan dalam bentuk peta. Komposit warna dibuat dengan memilih kombinasi kanal yang mempunyai nilai spektral paling tinggi untuk eceng gondok berdasarkan hasil analisis perbedaan spektral dari sampel vegetasi. Eceng gondok di danau mempunyai tingkat kehijauan dan aktifitas fotosintesis yang tinggi, sehingga memiliki pantulan yang tinggi pada kanal NIR dan SWIR, serta memiliki pantulan rendah pada kanal merah. Dengan kombinasi warna RGB (R: NIR+SWIR, G: NIR, B: NIR-Red) maka piksel eceng gondok akan mempunyai nilai tinggi pada warna R, G dan B, yang kemudian membentuk gabungan warna putih (Trisakti et al. 2014 : 399).

Data spasial berupa peta diolah dengan software Arcgis 10.7 menggunakan tools image analisis menghasilkan output peta yang menggambarkan pola sebaran eceng gondok dari tahun 2015 sampai dengan tahun 2020.

\section{HASIL DAN PEMBAHASAN}

Lokasi penelitian terletak di danau Tondano, wilayah Kabupaten Minahasa Provinsi Sulawesi Utara yang memiliki luas perairan \pm 4.600 ha. Danau Tondano secara geografis, terletak pada koordinat $1^{\circ} 17^{\prime} 19.67^{\prime \prime}$ LU - $1^{\circ} 17^{\prime} 47.80^{\prime \prime} \mathrm{LU}$ dan 12451'35.65" BT $124^{\circ} 57^{\prime} 53.31 "$ BT. Penelitian ini dilaksanakan pada bulan Januari s/d Juni 2020.

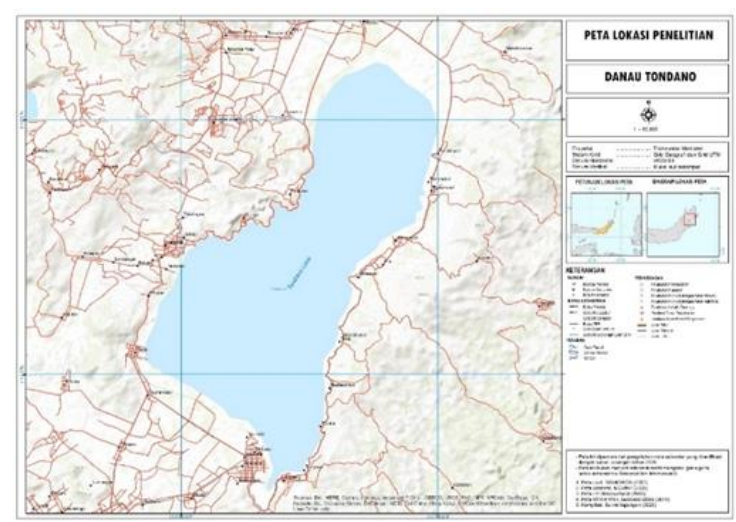

Gambar 1. Peta Lokasi Penelitian

Informasi sebaran spasial eceng gondok diperoleh dengan melakukan klasifikasi secara digital menggunakan Software ArcGis 10.7.1 dengan metode klasifikasi Maximum Likelihood Enhanced Neighbour. Hasil klasifikasi pola sebaran eceng gondok di danau tondano pada tahun 2015 sampai dengan tahun 2020, dijelaskan dalam bentuk peta berikut ini.

Pada citra landsat 8, hasil perekaman tanggal 28 April 2015 warna hijau pada gambar 2 merupakan sebaran eceng gondok tahun 2015. Luas sebaran eceng gondok sebesar 465.519 ha. Sebaran meliputi sisi barat, timur dan selatan. Eceng gondok sebagian besar terletak di pinggiran danau Tondano.

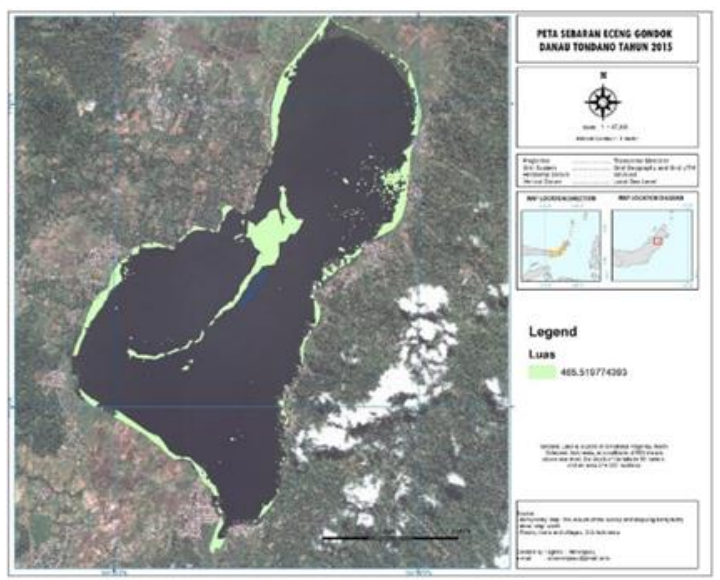

Gambar 2. Peta Sebaran Eceng Gondok Danau Tondano Tahun 2015

Pada citra landsat 8 hasil perekaman tanggal 8 Juli 2016 warna hijau pada gambar 3 merupakan sebaran eceng gondok. Luas sebaran 
eceng gondok 846.08 ha. Sebaran eceng gondok meliputi sisi utara, sebagian sisi timur dan barat. Eceng gondok sebagian besar berada di bagian outlet danau Tondano.

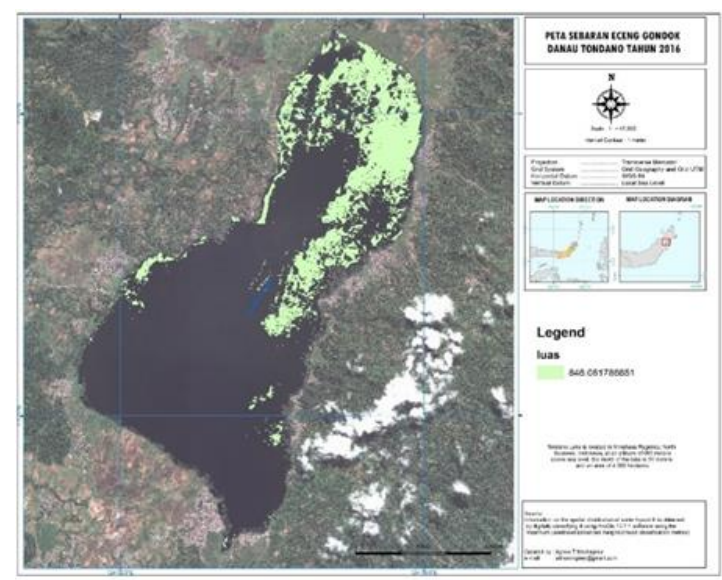

Gambar 3. Peta Sebaran Eceng Gondok Danau Tondano Tahun 2016

Pada citra landsat 8 hasil perekaman tanggal 10 Mei 2017 warna hijau pada Gambar 4 merupakan sebaran eceng gondok. Luas sebaran eceng gondok 999.695 ha. Sebaran eceng gondok meliputi sisi barat, timur dan utara. Eceng gondok sebagian besar terkonsentrasi pada bagian tengah danau Tondano.

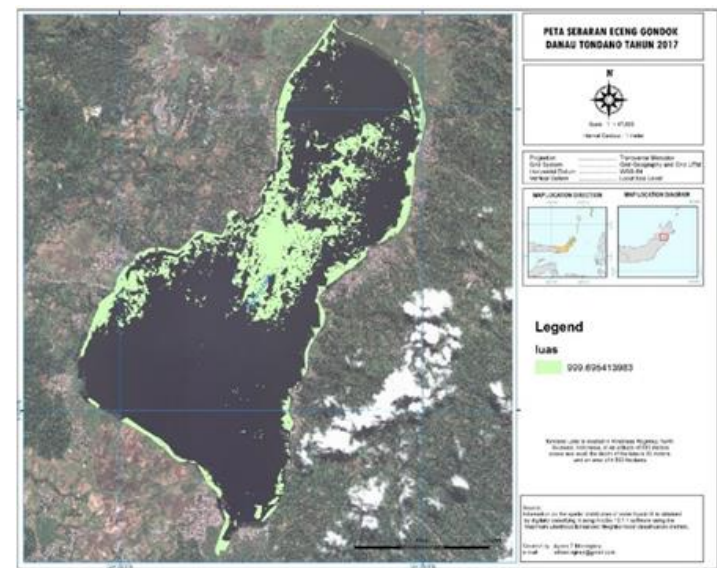

Gambar 4. Peta Sebaran Eceng Gondok Danau Tondano Tahun 2017

Pada citra landsat 8 hasil perekaman tanggal 6 Mei 2018 warna hijau pada Gambar 5 merupakan sebaran eceng gondok. Luas sebaran eceng gondok 675.870 ha, sebaran meliputi sisi utara, timur dan barat. eceng gondok sebagian besar terletak di pinggiran outlet danau Tondano.

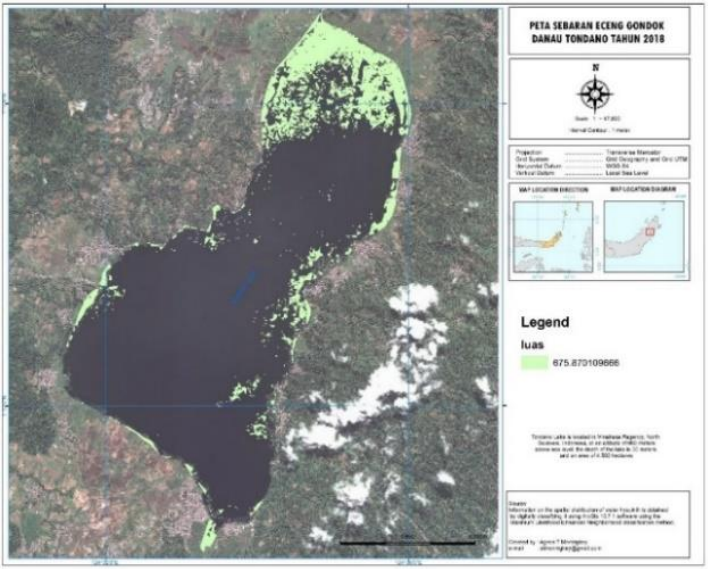

Gambar 5. Peta Sebaran Eceng Gondok Danau Tondano Tahun 2018

Pada citra landsat 8 hasil perekaman tanggal 28 Juli 2019 warna hijau pada Gambar 6 merupakan sebaran eceng gondok. Luas sebaran eceng gondok 366.360 ha, vegetasi air meliputi sisi barat, timur dan selatan. Eceng gondok sebagian besar berada di pinggiran danau Tondano.

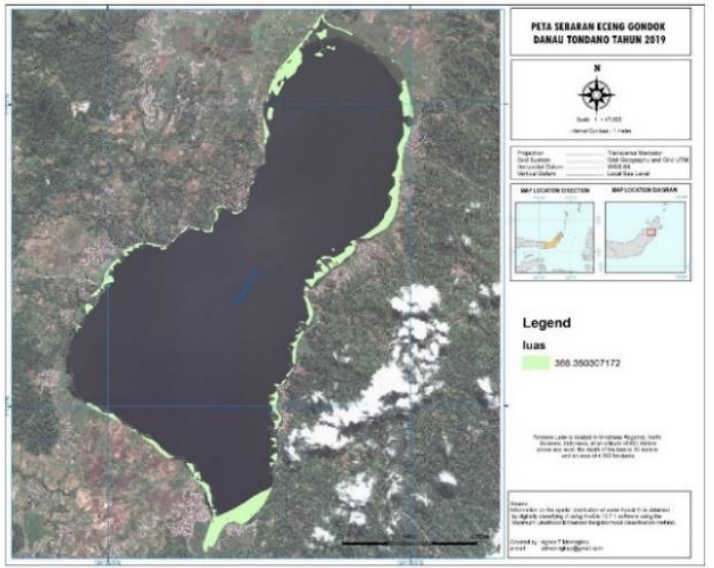

Gambar 6. Peta Sebaran Eceng Gondok Danau Tondano Tahun 2019

Pada citra landsat 8 hasil perekaman tanggal 18 Mei 2020 warna hijau pada Gambar 7 merupakan sebaran eceng gondok. Luas sebaran eceng gondok 995.797 ha, sebaran meliputi sisi utara, barat, timur dan selatan. Eceng gondok sebagian besar terletak di pinggiran danau Tondano. 


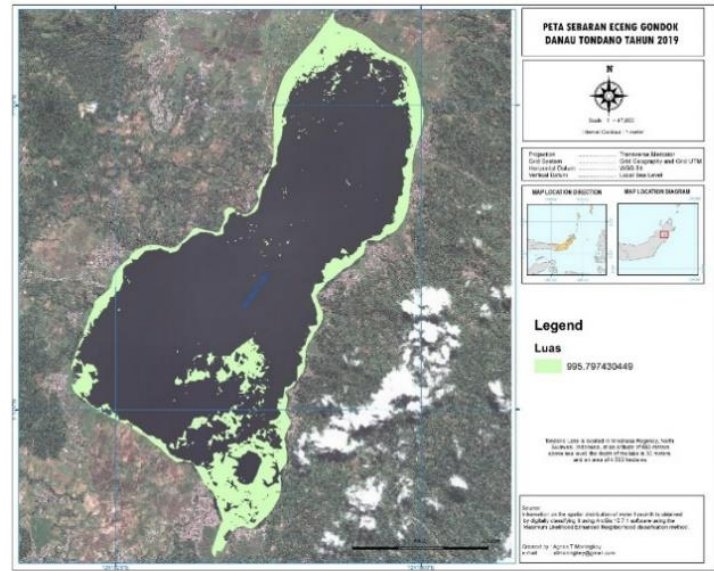

Gambar 7. Peta Sebaran Eceng Gondok Danau Tondano Tahun 2020

Pada tahun 2015 luas eceng gondok $465.59 \mathrm{Ha}$ di tahun 2016 mengalami peningkatan menjadi $848.08 \mathrm{Ha}$ bertambah 385.61 dari tahun sebelumnya, pada tahun 2017 luasan eceng gondok bertambah $153.615 \mathrm{Ha}$ menjadi $999.695 \mathrm{Ha}$, di tahun 2018 berkurang $323.825 \mathrm{Ha}$ menjadi $675.87 \mathrm{Ha}$, pada tahun 2019 sebaran eceng gondok berkurang 309.51 menjadi $366.36 \mathrm{Ha}$, di tahun 2020 bertambah $629.347 \mathrm{Ha}$ menjadi 995.797 Ha. Untuk mengetahui perbandingan pola sebaran eceng gondok di danau tondano tahun 2015 sampai dengan tahun 2020, dapat dilihat pada sajian diagram batang hasil perhitungan pada gambar di bawah ini.

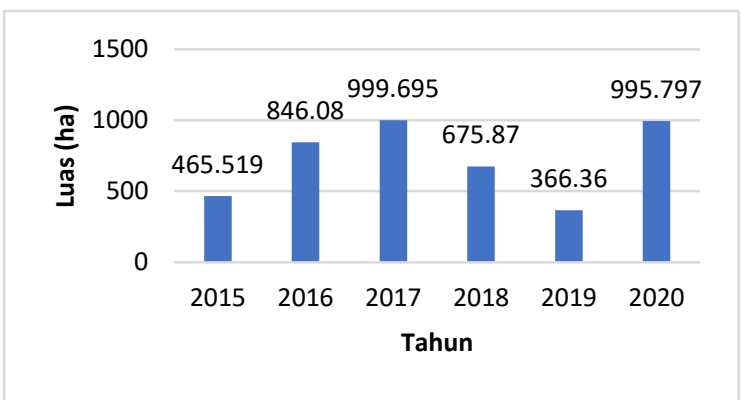

Gambar 8. Diagram Perubahan Pola Sebaran Eceng Gondok Danau Tondano Tahun 2015 s/d 2020.

Berdasarkan hasil analisis spasial sebaran eceng gondok tahun 2015 s/d 2020, dapat diketahui mengalami peningkatan dari tahun 2015 luas 465.59 ha, tahun 2016 luas $848 \mathrm{Ha}$, tahun 2017 luas 999.695. Terjadi perubahan penurunan luas eceng gondok di tahun 2018 luas 675.87 Ha, dan 2019 luas $366.36 \mathrm{Ha}$, tahun 2020 luas eceng gondok bertambah menjadi 995.797 Ha.

Pola sebaran eceng gondok pada perairan danau tondano, yang tidak terkendali telah menyebabkan terganggunya ekosistem atau fungsi perairan danau. Pertumbuhan dan perkembangan eceng gondok tersebut, mengakibatkan berbagai aktivitas masyarakat terganggu dan berdampak pada proses pendangkalan perairan danau serta merusak keindahan danau tondano. Rosyidy, dkk (2019) memaparkan kenaikan luas area eceng gondok cenderung terjadi pada musim hujan dan penurunan luas area eceng gondok terjadi pada peralihan musim dan musim kemarau. Faktor yang membuat luasan eceng gondok maupun luasan danau berubah disebabkan karena sedimentasi, musim (iklim), serta penggunaan lahan (Abimanyu, dkk 2016).

\section{KESIMPULAN}

Hasil analisis menunjukkan terjadinya perubahan luasan dari tahun 2015 sampai dengan tahun 2020 melalui informasi spasial pola sebaran eceng gondok pada danau tondano.

Perubahan sebaran eceng gondok di danau tondano setiap tahun dapat dipengaruhi oleh beberapa faktor seperti: cuaca (iklim), sedimentasi, ataupun penggunaan lahan di sekitar kawasan perairan.

\section{DAFTAR PUSTAKA}

Abimanyu, Kentasa, Eva Banowati, Ananto Aji, and Info Artikel. 2016. "Analisis Pemanfaatan Sumber Daya Alam Danau Rawa Pening Kabupaten Semarang." Geo-Image 5(1): 1-7.

Aprilliyana, Dian. 2015. "Pengaruh Perubahan Penggunaan Lahan Sub DAS Rawapening Terhadap Erosi Dan Sedimentasi Danau Rawapening." JURNAL PEMBANGUNAN WILAYAH \& KOTA 11(1): 103. http://ejournal.undip.ac.id/index.php/pw k/article/view/8661.

Fauzi Deswandri, and Fadhillah. 2018. "Variasi Waktu Terhadap Penyerapan Merkuri $(\mathrm{Hg})$ Oleh Eceng Gondok (Eichhornia Crassipes) (Studikasus: Air Danau Bekas PETI Di Jorong Jujutan, Nagari Lubuk Gadang, Kecamatan Sangir, Kabupaten Solok Selatan.” Bina Tambang 4(4): 1323.

Gerbono, A, and A Siregar. 2005. "Kerajinan Eceng Gondok." 
Juliani, Rita, Ruth Fika Ronauli Simbolon, Warmi Hartati Sitanggang, and Jon Berghauser Aritonang. 2017. "Pupuk Organik Enceng Gondok Dari Danau Toba." Jurnal Pengabdian Kepada Masyarakat 23(1): 220.

Krismono, Krismono, Amula Nurfiarini, Yayuk Sugianti, and Andika Luky Setiyo Hendrawan. 2018. "Pengelolaan Perikanan Di Danau Limboto Pasca Pengerukan." Jurnal Kebijakan Perikanan Indonesia 10(2): 63.

Kusrinah, Kusrinah, Alwiyah Nurhayati, and Nur Hayati. 2016. "Pelatihan Dan Pendampingan Pemanfaatan Eceng Gondok (Eichornia Crassipes) Menjadi Pupuk Kompos Cair Untuk Mengurangi Pencemaran Air Dan Meningkatkan Ekonomi Masyarakat Desa Karangkimpul Kelurahan Kaligawe Kecamatan Gayamsari Kotamadya Semarang." Dimas: Jurnal Pemikiran Agama untuk Pemberdayaan 16: 27-48.

Ratnani, Rita D, Indah Hartati, and Laeli Kurniasari. 2011. "Pemanfaatan Ecceng Gondok ( Eichornia Crassipes ) Untuk Menurunkan Kandungan COD ( Chemical Oxygen Demond ), PH , Bau , Dan Warna Pada Limbah." momentum 7, No. 1: 41-47.

Rosyidy, Muhamad Khairul, Qonita Putri Ashilah, and Putut Ash. 2019. "Pemanfaatan Citra Sentinel-2 Untuk Monitoring Sebaran Dan Luasan Eceng Gondok Secara Spasio-Temporal Sebagai Upaya Menjaga Kondisi Air Dan Sanitasi Di Inlet Waduk Saguling, Jawa Barat Application of Sentinel-2 Imagery for Monitoring Area and Distribution." (February): 31-40.

Sitindaon, Pasca, and Setyono Tyasmoro. 2018. "Pengaruh Kompos Eceng Gondok Terhadap Pertumbuhan Bibit Pada Pembibitan Pre Nursey Kelapa Sawit (Elaeis Gueneensis Jacq.)." : 2713-21.

Sittadewi, Euthalia Hanggari. 2011. "Fungsi Strategis Danau Tondano, Perubahan Ekosistem Dan Masalah Yang terjadi." Jurnal Teknologi Lingkungan.

Tangio, Julhim S. 2013. "Adsorpsi Logam Timbal ( $\mathrm{Pb}$ ) Dengan Menggunakan Biomassa Enceng Gondok ( Eichhorniacrassipes )." Jurnal Entropi VIII: 500-506.
Trisakti, Bambang et al. 2014. 7 Pemanfaatan Penginderaan Jauh Satelit Untuk Pemantauan Daerah Tangkapan Air Dan Danau. http://pusfatja.lapan.go.id/files_uploads_ ebook/indikator/revisi buku Lapan Danau 220215.pdf.

Wantasen, S et all. 2015. "Gerakan Penyelamatan Danau (GERMADAN) Tondano." 